\title{
Religiosity and Individual Agency: Denominational Affiliation, Religious Action, and Sense of Control (SOC) in Life
}

\author{
Jae-Mahn Shim D
}

check for

updates

Citation: Shim, Jae-Mahn. 2021. Religiosity and Individual Agency: Denominational Affiliation, Religious Action, and Sense of Control (SOC) in Life. Religions 12: 117. https:// doi.org/10.3390/rel12020117

Received: 14 January 2021

Accepted: 9 February 2021

Published: 11 February 2021

Publisher's Note: MDPI stays neutra with regard to jurisdictional claims in published maps and institutional affiliations.

Copyright: (C) 2021 by the author. Licensee MDPI, Basel, Switzerland. This article is an open access article distributed under the terms and conditions of the Creative Commons Attribution (CC BY) license (https:/ / creativecommons.org/licenses/by/ $4.0 /)$.
Department of Sociology, Korea University, 145 Anam-ro, Seoul 02841, Korea; jaemahn.shim@gmail.com

\begin{abstract}
By reporting findings from Wave 6 of the World Values Survey, this paper presents a renewed understanding of the relationship between religiosity and individual agency that is defined as sense of control (SOC) in life. In doing so, it proposes two conceptual articulations of religiosity. First, it articulates religiosity to be composed of categorical (i.e., denominational affiliation) and substantive (i.e., religious action) aspects. Second, it articulates substantive religious action to be multivocal, involving individual-affective, individual-practical, and collective-practical action. The paper finds that categorical denominational affiliation has varying effects on SOC, whereas substantive religious action mediates these effects in such a way that it consistently boosts SOC. A positive association between denominational affiliation (vs. non-affiliation) and SOC becomes smaller when religious action is accounted for. A negative association becomes greater when religious action is accounted for. In sum, the paper argues for the positive mediating effect of religious action on the varying relationship between denominational affiliation and SOC.
\end{abstract}

Keywords: religiosity; denominational affiliation; religious action; sense of control (SOC); agency

\section{Introduction}

Agency, defined as the capacity for individuals to lead meaningful lives in the world or the capacity to engage the social world (Emirbayer and Mische 1998, p. 963), is one of the central presuppositions (i.e., the reality presupposed) (Alexander 1987, p. 10) and questions (i.e., the reality to be investigated) (Joas and Knöbl 2009, p. 18) in sociology. Recent conceptual reviews provide systematic updates on the development of this notion (Glaeser 2016; Joas and Beckert 2006). Parallel interests exist in subfields of empirical research under different notions, such as self-efficacy (Downey and Moen 1987), mastery (Pearlin et al. 1981), internal locus of control (Masters and Wallston 2005), power/governmentality (Reed 2013; Foucault [1978] 1991; Foucault 1982), and rationality (Kalberg 1980). Studies on sense of control (SOC) in life, defined as the belief that one masters, controls, and shapes one's own life (Ross and Mirowsky 2013), draw on these interests.

One essential insight from the literature on agency at large, and SOC in particular, is that agency can involve both active and passive intentionality, both the control of one's self and the surrender of the self to supra-individual entities, and both solitude and social relations (Joas and Beckert 2006; Joas 1996; Masters and Wallston 2005). The literature on power and governmentality states that one can be empowered once the person gets involved and dominated in multiple power relations (Foucault 1982; Foucault [1978] 1991; Reed 2013). Although this notion of agency as presiding in submission to forms of supra-individual sociality, such as social relations, collectivities, and transcendental entities, is pervasive in sociological theories, there have not been many empirical studies investigating how such agency is revealed in specific social practices (Mauss [1950] 1990, pp. $x-$ xii).

Some studies on religious involvement are interested in how religiosity, or the extent to which one submits one's life to supra-individual divine powers, is related to the ways in which individuals cope with their life problems and sense of control (Pargament 2002; 
Pargament et al. 1988; Allport 1950; Ellison and Burdette 2012; Norris and Inglehart 2011). Since divine powers are a unique type of supra-individual sociality to which individuals submit themselves, empirical investigations of religious involvement should serve as a significant empirical field that can adjudicate the sociological insight on the relationship between submission to sociality and SOC. However, the literature on religious involvement has failed to produce satisfactory answers.

Firstly, the literature is loaded with agnosticism. It has shown that effects of religiosity on SOC are varying (i.e., sometimes positive; other times negative or non-existent) from one set of empirical measures of religiosity to another or from one study population to another (Ellison and Burdette 2012; Jung 2019; Pargament 2002; Schieman 2008; Schieman et al. 2005; Pascoe et al. 2016; Speed and Fowler 2017; Clements 2014). Based on these inconsistencies, the current literature suggests that the sociological imagination of actors' SOC along with their submission to sociality, especially to deity as its religious kind, is doubtful. Resolving this agnosticism requires a careful conceptual reconsideration of what constitutes religiosity and, accordingly, which measures can be simultaneously used in model specification (Ammerman 2020; Glock 1962).

Meanwhile, a methodological fix on study populations rather than a conceptual revisit to religiosity has recently been made by a study that uses a cross-national dataset to specify a global model that includes as many study populations as possible (Jung 2019). By identifying a macro-national factor that conditions the effects of religiosity on SOC among different study populations, Jung (2019) presents a substantive theoretical gain, compared to the heretofore unwitting and unorganized reports of agnosticism. The study argues that identical religious practices, such as prayers, have a positive effect on SOC in national contexts where these practices are socially valued, but a negative effect in other contexts where such practices are socially shunned. This finding highlights the importance of the secular social environment of sacred religious practices and reaffirms the view that social relations that constitute the meaning of religious practices are the most relevant.

While it improves the understanding of the impacts of religiosity on SOC out of agnosticism, Jung (2019) methodologically inspired reformulation does not allow for anything inherently sacred in religious practices. For example, rather than being solitary spiritual engagements with deity, private prayers are theorized to be secular social performances whose meanings are most effectively modified by other people's positive or negative valuations of prayer. Wittingly or not, the study presents religiosity as submission more to sociality of a secular kind (i.e., social norms and relations) than to sociality of a sacred kind (i.e., deity) (for a similar critique, see Ammerman 2020, p. 9). In this sense, I call this second limitation a Durkheimian bias that does not grant anything genuinely religious to religious practices (Joas and Beckert 2006, p. 276; Durkheim [1912] 1995).

In sum, the current literature agrees on the inconsistent effects of religious practices on SOC (i.e., agnosticism). At the same time, it paradoxically agrees on the relatively consistent positive effects of religious practices only when religious practices are qualified as secular social practices (i.e., Durkheimian bias). Therefore, the literature doubts consistent effects of religious practices that are sacred in nature. However, due to the following conceptual deficiency and methodological limitation in the literature, I hesitate to settle into these limits and, instead, propose a renewed understanding of religiosity and its effects on SOC.

The literature has not paid due attention to differences in SOC between people who are affiliated with religious denominations (i.e., religious affiliates) and those who are not (i.e., non-affiliates). The literature has typically treated affiliational status as a potential confounder that interferes in the relationship between SOC and religiosity represented by various measures other than affiliational status (e.g., prayer and service attendance) (Jung 2019; Ellison and Burdette 2012). In doing so, the literature has not explicitly treated affiliational status as a measure of religiosity in regression models.

This treatment ignores the idea that affiliational status can significantly serve as a categorical measure of religiosity since affiliates are reasonably more religious than nonaffiliates if categorically (Reeves et al. 2012; Wuthnow 2010; Perkins 1985; Vernon 1968; 
Voas 2007). While overlooking affiliational status, the literature restricts religiosity to a particular set of empirical measures, such as prayer, religious service attendance, adherence to biblical teachings, etc. Doubtlessly, these often-used measures are legitimately reflective of the substantive and practical elements of religiosity. Nevertheless, they are not inclusive of categorical and nominal measures of religiosity such as affiliational status. This conceptual discrimination against affiliational status in relation to other measures of religiosity needs to be rectified.

Once one takes affiliational status as a measure of categorical religiosity, it is not recommended to simply incorporate affiliational status as a control variable into models that already have other measures of substantive religiosity regressed upon SOC. This is because these models would produce fluctuating regression coefficients for the measures of religiosity and would be vulnerable to misspecification errors due to the multicollinearity between affiliational status and other measures of religiosity. In statistical terms, various measures of religiosity would behave unstably in the presence of another de facto measure of religiosity, i.e., affiliational status. One corresponding methodological correction is to develop a set of models that can examine how different measures of religiosity, including affiliational status, relate to one another and how they affect SOC.

To this end, I first propose to take affiliational status as a measure of categorical religiosity, and other measures as a set of measures of substantive religiosity. Specifically, I conceptualize the latter as measures of religious action, as they refer to substantive practices, as opposed to the former, which refers to the categorical status of whether or not one belongs to a religious denomination. Following this conceptual articulation, I then develop models of the mediating effects of religious action (i.e., substantive religiosity) upon the association between affiliational status (i.e., categorical religiosity) and SOC. These models are equipped, firstly, to specify how affiliational status is associated with SOC and, subsequently, to specify the extents to which measures of religious action mediate that association. This modeling process avoids the issues with multicollinearity-driven misspecification errors that emerge from studies that contemporaneously incorporate affiliational status together with measures of religious action in a single model (Clements 2014; Olson and Warber 2008).

My conceptual elaboration of categorical religiosity and substantive religiosity provides an updated view of how religiosity is practiced. This conceptual revision highlights that individuals practice religiosity through both categorical status and substantive action. In addition, I subsequently unpack substantive religious action into various measures by drawing on the literature about the coexistence of sacred and secular practices in religious action. In particular, my conceptualization recognizes a wide range of empirical measures of practices and proposes the notion of religious action as multivocal action that cuts across both secular and sacred practices, and both free and obligated practices. Against this conceptual framework, the empirical analysis verifies that categorical religiosity is related to SOC via multivocal practices of religious action. Ultimately, this analysis indicates that religiosity is multivocal in that it is both categorical and substantive, both secular and sacred, and both free/participatory and constrained/obligatory. I argue that individual agency exists in religiosity of such a multivocal nature.

To these effects, I examine responses in the latest wave (Wave 6) of the World Values Survey that includes various measures of religiosity and SOC. Given the heterogeneity of dominant religions and their social standings among different countries, and the resultant inadequacy of starting the investigation by specifying a cross-national model while taking a bird's eye view, I instead take a context-specific approach that considers a specific study population and ultimately expands to a supplementary cross-national analysis. First, in the main analysis of this paper, I examine responses from S. Korea, where half of the population reports belonging to a denomination for decades (Kim et al. 2009); furthermore, this exemplary religiosity is found to be related to the tumultuous senses of existential security in the state-building process (Lee and Suh 2017). Secondly, I investigate two other East Asian countries (Japan and China) in a supplementary analysis. I examine 
these countries because of their geo-cultural similarities as well as their differences in the proportion of religious affiliates, dominant denominations, religious action, and level of SOC. When paired with the cultural similarities, these differences provide an immediate empirical setting against which the generalizability of the proposed theoretical model can be tested. Finally, I conduct an additional multilevel analysis of 49 countries, which supports the generalizability even to countries in other parts of the world. Result tables of these supplementary analyses are accessible online.

\section{The Multivocality of Religiosity and SOC}

Drawing on the literature of religious practices, I propose a conceptualization of religiosity as being composed of the categorical and nominal status of affiliation on the one hand (i.e., categorical religiosity) and, on the other, of the substantive practices such as affective confession, prayer, and service attendance (i.e., substantive religiosity). In order to stress practices in substantive religiosity, I further conceptualize substantive religiosity particularly as religious action. In this conceptual formulation, religious action is defined as a variety of practices, including feelings, beliefs, and activities, that people engage with in relation to supernatural entities, reflecting a practice approach to religion (Ammerman 2020). In the following section, I elaborate on this conceptual framework and hypothesize how various aspects of religiosity are related to one another and, ultimately, to SOC.

\subsection{Categorical Religiosity in Affiliational Status}

Affiliational status refers to whether one is affiliated with a religious denomination and which religious denomination one belongs to. Some studies treat it as distinct from religiosity, which potentially confounds the relationship between religiosity and SOC (Clements 2014; Jung 2019; Olson and Warber 2008; Ellison and Burdette 2012). By contrast, other studies treat it as a measure of religiosity itself, if nominal and categorical (Reeves et al. 2012; Wuthnow 2010; Perkins 1985; Vernon 1968; Voas 2007; Glock 1962).

The nominal and categorical aspect of religiosity in affiliational status can clearly be seen in studies about religious none(s), or those individuals who claim no religion. People with no religion behave differently from religious affiliates in the belief in God, service attendance, etc. (Vernon 1968), although these non-affiliates involve heterogeneous individuals; they include atheists, agnostics, and unchurched believers (Baker and Smith 2009) - both "the non-affiliated" who have never had religion in life and "the unaffiliated" who once had a religious belonging but currently do not have any via disaffiliation amid life events (Thiessen and Wilkins-Laflamme 2017). In addition, it is not uncommon that non-affiliates seek spiritual comfort and attend religious services in the face of health problems (Ferraro and Kelley-Moore 2001). Nevertheless, these studies suggest that non-affiliates are less likely to engage in religious practices than affiliates to varying extents. Affiliates, for their part, are largely more engaged in religious practices than non-affiliates (Ferraro and Kelley-Moore 2001; Vernon 1968).

To capture this omnibus nature of affiliational status, studies conceptualize it as nominal (Wuthnow 2010; Perkins 1985) or categorical (Reeves et al. 2012) religiosity, and consider affiliates to be more religious than non-affiliates. At the same time, these studies recognize that religiosity based upon affiliational status is only categorical in that it does not sufficiently describe the specific compositions and levels of religiosity, and that categorical religiosity does not necessarily reflect religiosity in practice. Accordingly, some studies juxtapose categorical religiosity against intense and true religiosity (Schnabel and Bock 2017; Voas and Chaves 2018; Bobkowski and Kalyanaraman 2010; Smith and Snell 2009). Furthermore, categorical religiosity sometimes appears to reflect whether one conforms to nationalist cultures rather than religious norms (e.g., pro-immigration norms inspired by the world brotherhood in religion). Religious affiliates in European countries where their affiliated denominations are prevalent and taken as the national culture show surprisingly more negative attitudes than non-affiliates toward immigration (Storm 2018; Storm 2011). 
Similarly, religious affiliates among American and British students are not necessarily supportive of egalitarianism and anti-racism (Perkins 1985).

Taken together, these studies suggest that affiliational status serves as a measure of religiosity, although it cannot by itself elaborate on specific aspects of religiosity. Therefore, I initially hypothesize that categorical religiosity will lead to more SOC. Affiliates are those who belong to an organized religious denomination and, simultaneously, most likely engage in religious action that has multiple implications for SOC, which I will elaborate in the next section. Compared to non-affiliates, affiliates are expected to have greater SOC (Hypothesis 1), due to having a greater sense of belonging to a socially sanctioned organization or being more deeply involved in religious action.

\subsection{Substantive Religiosity in Religious Action}

I further hypothesize that the positive association between categorical religiosity and SOC will be explained by the mediation of substantive religiosity, or religious action that is practiced by individuals on an individual or collective dimension. To this end, I draw on the literature of religious practices and propose an analytical framework that highlights the multivocality of religious action. In this framework, I conceptualize religious action to be composed of both secular and sacred aspects. Each aspect is in turn instantiated by several specific practices that are significant for SOC.

\subsubsection{The Secular Aspect}

The binary distinction and the dialectical connection between the secular and the sacred are well established in the sociological literature of religion (Eliade 1959; Durkheim [1912] 1995; Norris and Inglehart 2011; Demerath et al. 1998; Taylor 2007). The secular is taken to consist of this-worldly, material, and low-order existences and experiences, while the sacred is defined as other-worldly, ideal, transcendental, and higher-order entities and experiences (Durkheim [1912] 1995, pp. 33-39; Eliade 1959, pp. 11-12). Drawing on the binary, studies find that sacred experiences are not confined only within conventional institutions of religion; sacred experiences pervade in pseudo-religious movements (Chan 2000) and nonreligious fields of work and politics as well (Demerath 2000; Lynch 2012; Friedland 2013). In addition, practices in religion are full of secular projects (such as money-making) as well as sacred commitments (Demerath et al. 1998; Chan 2000; Lazarus 2019; Heuser 2016). Religious action is thus composed of both secular and sacred elements.

The secular elements of religious action are evidenced in various studies. American churches are historically found to bring secular clubs and associations within their organizational structures in response to people's pursuit for communities whose sacred-vs.-secular natures are of little concern to the people (DiMaggio 1998). The "Gospel of prosperity" or material prosperity-oriented faith among African Christians (Heuser 2016; Lazarus 2019) and new-age religionists in Asia (Chan 2000) attest to the close link between the secular and the sacred. Similarly, religious action such as churchgoing in European countries is not so much aligned with proclaiming religious norms of supra-national solidarity as it is with acquiring associational belongings within nationalism (Storm 2018; Storm 2011). Among Nigerians, shrines and their kinship relations around them are mobilized as invaluable political and economic foundations in contemporary politics (Lazarus 2019). After all, given that religion is a "human enterprise" of establishing "a sacred cosmos" (Berger [1967] 2011, p. 26), it is fundamental that secular elements are inherent in religious action. Before anything else, people seek religion as they seek collectivities, totality, and unity above solitary individuals (Durkheim [1912] 1995, p. 44; Kinnvall 2004, p. 759). To the extent that memberships to civic associations boost SOC via the material, relational, and psychological resources that the associations offer (Holdo 2018, p. 358; Anheier and Kendall 2002), affiliates to religious denominations are likewise expected to have higher senses of control than non-affiliates. In addition, affiliates become more active in joining other civic associations beyond religious organizations (Ellison and George 1994; McIntosh and Alston 1982). Therefore, the relative advantages in SOC among affiliates will be ex- 
plained by the mediation of this civic associational action that is involved in and boosted by religious affiliation. I hypothesize that the advantage of SOC among affiliates compared to non-affiliates will become smaller when civic associational action is considered in the model (Hypothesis 2a).

\subsubsection{The Sacred Aspect}

Regarding the sacred elements of religious action, I find studies about the multidimensional meanings of religion for individuals to be relevant (Clements 2014; Olson and Warber 2008; Voas 2007; Saroglou 2011). These studies largely agree on presenting multidimensionality with three meanings: "behaving", which is conceptualized as either "commitment" (Olson and Warber 2008) or "practices" (Voas 2007) and measured in terms of the subjective importance of God (Olson and Warber 2008), prayer (Olson and Warber 2008), and service attendance (Clements 2014; Olson and Warber 2008); "believing”, which is, without any conceptual formulation, measured by the subjective importance of God (Clements 2014), the literalism ascribed to the holy scriptures (Clements 2014; Olson and Warber 2008), and theological exclusivity (i.e., one true religion) (Clements 2014); and "belonging", which is, without any conceptual definition, measured by affiliational status.

I find it problematic to view affiliational status as an aspect of religious action without a clear conceptualization. I have conceptualized it as categorical religiosity based on the results of other existing studies. The other two elements ("behaving" and "believing") clearly involve practices, whether they be behavioral or affective, and thus constitute substantive religious action. Drawing on these two notions, I therefore propose that religious action consists of affective action in which individuals confess and display their subjective belief in sanctity (i.e., individual-affective action), such as the subjective belief in God and the importance of God in life; religious action also consists of practical action in which individuals act out their religiosity in concrete behaviors at the individual level (i.e., individual-practical action, such as prayer) and at the collective level (i.e., collective-practical action, such as service attendance). As to how these three sacred aspects of religious action are related to affiliates, I propose the following three hypotheses.

Affiliates are more likely to engage in individual-affective religious action which is positively associated with SOC. The personal confession and conviction of the existence and importance of a divine other in one's life is likely to increase SOC to the extent that the divine other is viewed as a partner/friend or a deliverer in one's life matters (Schieman et al. 2005; Ellison 1993; Cole and Pargament 1999). The more salient this affective action is, I hypothesize, the more SOC individuals will show. It is affiliates who are more likely to engage in the affective action than non-affiliates. Therefore, the relative advantages in SOC among affiliates will be explained by the mediation of individualaffective religious action; in other words, the advantage of SOC among affiliates compared to non-affiliates will become smaller when individual-affective action is considered in the model (Hypothesis 2b).

Affiliates are more likely to engage in individual-practical action which is positively associated with SOC. Through individual-practical action such as prayer, individuals reaffirm their conviction of the divine existence and, furthermore, form a spiritual relation and engage in intimate interactions with the divine existence (Black 1999; Pollner 1989). The more practical action one engages in, the stronger one's belief in and relation with divinity will be and, accordingly, the stronger one's SOC will be. Therefore, the relative advantages in SOC among affiliates will be explained by the mediation of individual-practical religious action that affiliates engage in; the advantage of SOC among affiliates compared to nonaffiliates will become smaller when individual-practical action is considered in the model (Hypothesis 2c).

Affiliates are more likely to engage in collective-practical action which is positively associated with SOC. The effects of collective rituals and practices (and collective effervescence in these practices) upon the formation of individuality as well as sociality are expounded by classic works (Joas and Beckert 2006, p. 276; Durkheim [1912] 1995). One 
can expect similar effects from the collective practices of worship services to increase SOC; in collective worship services, participants experience ecstatic self-transcendence, which reinforces their sense of self and agency (Gritzmacher et al. 1988). In addition, analogous to individual-practical action, participants in collective practices such as worship services form substantive relations with a divine other, on the one hand, and, on the other, with fellow worshipers and even with people outside of the place of worship (Krause and Hayward 2013). Therefore, the more often one participates in collective practices, the stronger one's SOC will be. Therefore, the relative advantages in SOC among affiliates will be explained by the mediation of collective-practical religious action; the advantage of SOC among affiliates compared to non-affiliates will become smaller when collective-practical action is considered in the model (Hypothesis 2d).

\section{Data and Methods}

My main analysis in this paper uses Wave 6 of the World Values Survey conducted in S. Korea in 2010. Supplementary analyses use data from the same wave administered in two East Asian countries (online Supplementary Table S1 for Japan and Table S2 for China) and 49 countries in the world (online Supplementary Table S3 for a multilevel cross-national analysis). In all these analyses, I use the same set of variables as well as the same statistical logic of explanation in identifying the effects of mediating variables (Davis 1985; Shrout and Bolger 2002). Briefly, when the incorporation of theoretically justified mediators between an independent variable and a dependent variable results in changes in the regression coefficient of the independent variable (i.e., a change from a significant coefficient to an insignificant one in the case of full mediation; a weakening of a significant coefficient to a smaller and yet significant coefficient in the case of partial mediation), the original association between the independent and dependent variables is interpreted to be explained by the mediators.

The dependent variable, SOC, is measured by responses ranging from 1 (not at all) to 10 (a great deal) to the question, "how much freedom of choice and control do you feel you have over the way your life turns out?" As it is an ordinal variable, I report the results from the ordered logistic regression models in Stata (ologit). I have attempted to use the generalized ordered logistic regression models (gologit2) to guard against any possible violations of proportionality assumption (Long and Freese 2014), yet failed to specify generalized estimates due to the limitation of the current data. As an alternative robustness check, I specify OLS estimates treating SOC as a continuous variable (online Supplementary Tables S4-S7).

The focal independent variable is categorical religiosity, referring to various affiliates, such as Buddhists, Catholics, Protestants, and others, against the reference group of nonaffiliates. I use the following set of potential confounders for the relationship between categorical religiosity and SOC: age, gender, marital status, educational level, employment status, and subjective income strata (Table 1 for descriptive statistics).

I use four groups of mediators comprising religious action. Civic associational action is measured by the total number of associational memberships that a respondent has in such associations as recreational organizations, cultural organizations, political parties, labor unions, self-help organizations, etc. Individual-affective action is measured by belief in God ("Do you believe in God? Yes/No"), perceived importance of God ("How important is god in your life? 1 (Not at all) to 10 (Very important)"), and self-rated religiosity ("No matter whether you go to church, are you a religious person? Atheist, Not religious, Religious"). Individual-practical action is measured by prayer frequency ("How often do you pray to God?"), while collective-practical action is measured by the frequency of religious service attendance ("How often do you attend religious services?"). 
Table 1. Descriptive statistics $(\mathrm{N}=968)$.

\begin{tabular}{|c|c|c|c|c|c|}
\hline Variable & Frequency & $\%$ & Variable & Frequency & $\%$ \\
\hline SOC & & & Service Attendance & & \\
\hline 1 & 8 & 0.8 & never & 231 & 23.9 \\
\hline 2 & 17 & 1.8 & once a year or less often & 254 & 26.2 \\
\hline 3 & 36 & 3.7 & only on holy days & 154 & 15.9 \\
\hline 4 & 66 & 6.8 & once a week & 123 & 12.7 \\
\hline 5 & 137 & 14.2 & more than once a week & 206 & 21.3 \\
\hline 6 & 133 & 13.7 & Gender & & \\
\hline 7 & 199 & 20.6 & male & 482 & 49.8 \\
\hline 8 & 213 & 22.0 & female & 486 & 50.2 \\
\hline 9 & 87 & 9.0 & Marital status & & \\
\hline 10 & 72 & 7.4 & with a partner & 598 & 61.8 \\
\hline Affiliational status & & & wid/div/sep & 61 & 6.3 \\
\hline non-affiliate & 405 & 41.9 & single & 309 & 31.9 \\
\hline buddhist & 172 & 17.8 & Education level & & \\
\hline protestant & 223 & 23.0 & less than elementary & 9 & 0.9 \\
\hline catholic & 162 & 16.7 & elementary & 84 & 8.7 \\
\hline other & 6 & 0.6 & secondary & 306 & 31.6 \\
\hline Associational memberships & & & some college & 132 & 13.6 \\
\hline Mean 1.6, SD 2.1, Min 0 Max 16 & & & college or more & 437 & 45.2 \\
\hline Belief in God & & & Employment status & & \\
\hline yes & 524 & 54.1 & unemployed & 337 & 34.8 \\
\hline no & 444 & 45.9 & self-employed & 188 & 19.4 \\
\hline Importance of God & & & full-timer & 312 & 32.2 \\
\hline Mean 5.6, SD 2.9, Min 1, Max 10 & & & part-timer & 69 & 7.2 \\
\hline Self-rated religiosity & & & other & 62 & 6.4 \\
\hline atheist & 300 & 31.0 & Subjective income strata & & \\
\hline not religious & 345 & 35.6 & 1 low & 36 & 3.7 \\
\hline religious & 323 & 33.4 & 2 & 46 & 4.8 \\
\hline Prayer frequency & & & 3 & 103 & 10.6 \\
\hline never & 219 & 22.6 & 4 & 150 & 15.5 \\
\hline once a year or less often & 222 & 22.9 & 5 & 249 & 25.7 \\
\hline only on service days & 141 & 14.6 & 6 & 174 & 18.0 \\
\hline several a week or everyday & 205 & 21.2 & 7 & 141 & 14.6 \\
\hline \multirow[t]{4}{*}{ several times a day } & 181 & 18.7 & 8 & 55 & 5.7 \\
\hline & & & 9 & 6 & 0.6 \\
\hline & & & 10 high & 8 & 0.8 \\
\hline & & & Mean 42.1, SL & 19, Max 83 & \\
\hline
\end{tabular}

\section{Results}

Religious affiliates are found to have greater SOC than non-affiliates. As shown in Panel 1 of Figure 1, the numbers of people who answer that they have higher levels of SOC (such as 10,9, and 8) are the greatest among Protestants (the solid line), followed in order by Catholics (the long-dashed line) and Buddhists (the short-dashed line). These numbers are the smallest among non-affiliates (the dotted line). Therefore, the lines for affiliates lean to the right (i.e., higher mean levels of SOC: 7.0 for Protestants; 6.7 for Catholics and Buddhists) whereas that for non-affiliates leans to the left (mean SOC 6.5).

This pattern remains the same when a set of confounders is controlled in Model 1 of Table 2. Protestants, Buddhists, and Catholics are likely to have higher levels of SOC compared to non-affiliates. The positive logit coefficients of Protestants $(\alpha=0.01)$, Buddhists $(\alpha=0.10)$, and Catholics confirm the pattern. 


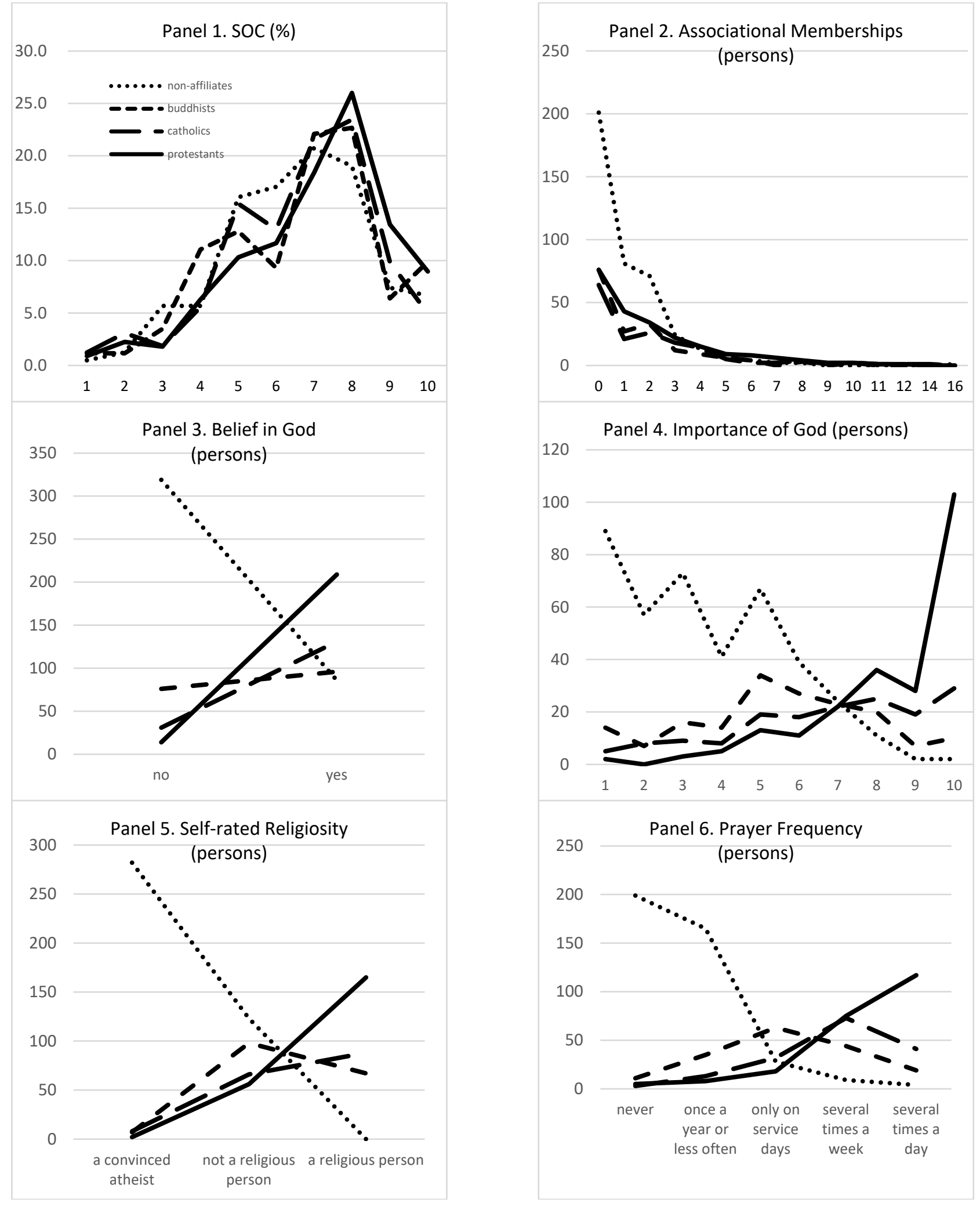

Figure 1. Cont. 


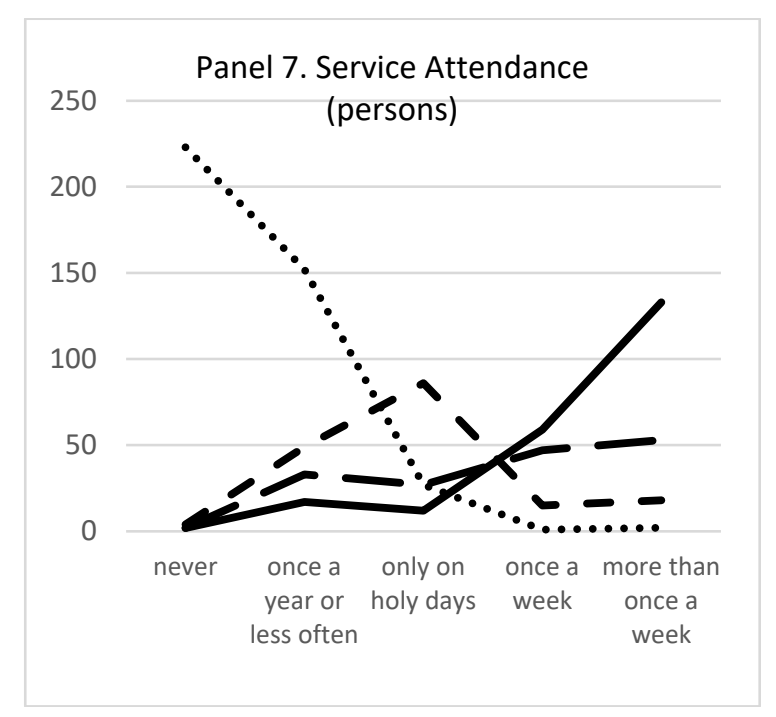

Figure 1. SOC and religious action by affiliational status.

Table 2. Logged odds ratios from ordered logistic regression models of SOC upon affiliational status, mediators, and other covariates.

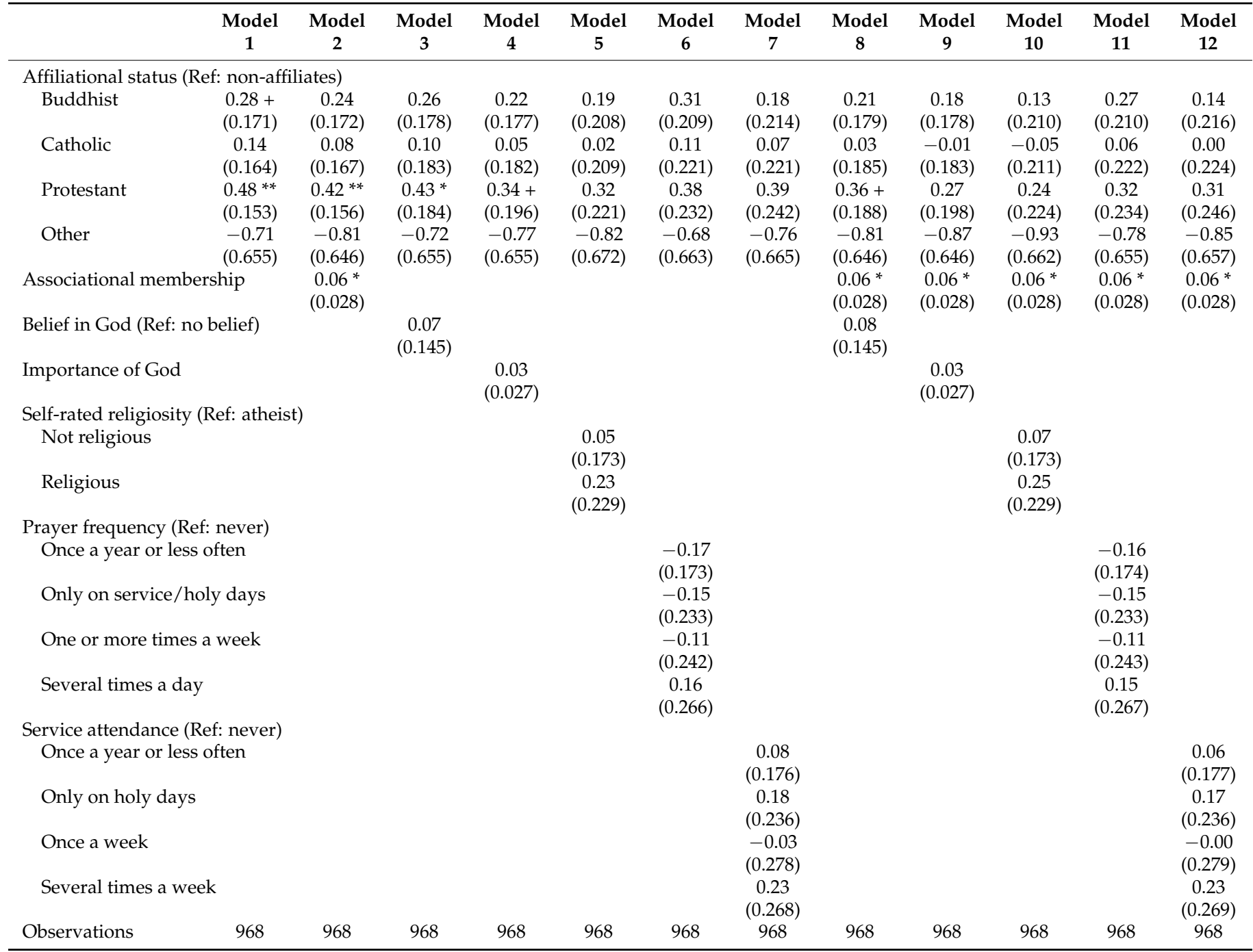

Note: standard errors in parentheses; ${ }^{* *} p<0.01,{ }^{*} p<0.05,+p<0.1$; all models include an identical set of control variables, such as age, gender, marital status, educational level, employment status, and subjective income strata. 
To visualize the pattern in terms of the predicted probabilities of having certain levels of SOC, I change the logit coefficients in Table 2 into probabilities for a hypothetical person (i.e., a mean-aged, college-or-more-educated, and married female who is a part-time worker with the mean income) in Figure 2. The bars in the figure refer to the corresponding probabilities of having 10 in SOC (i.e., the highest level of SOC) in the upper panel and 5 in SOC (i.e., one of the low levels of SOC) in the lower panel, for the hypothetical person who is a Protestant (the far left group of bars), a Buddhist (the middle group of bars), or a Catholic (the far right group of bars) vis-à-vis those probabilities for the hypothetical person who is a non-affiliate; that is, the bars refer to the probability differences between affiliates and non-affiliates. The solid black bars refer to the probability differences based on Model 1.

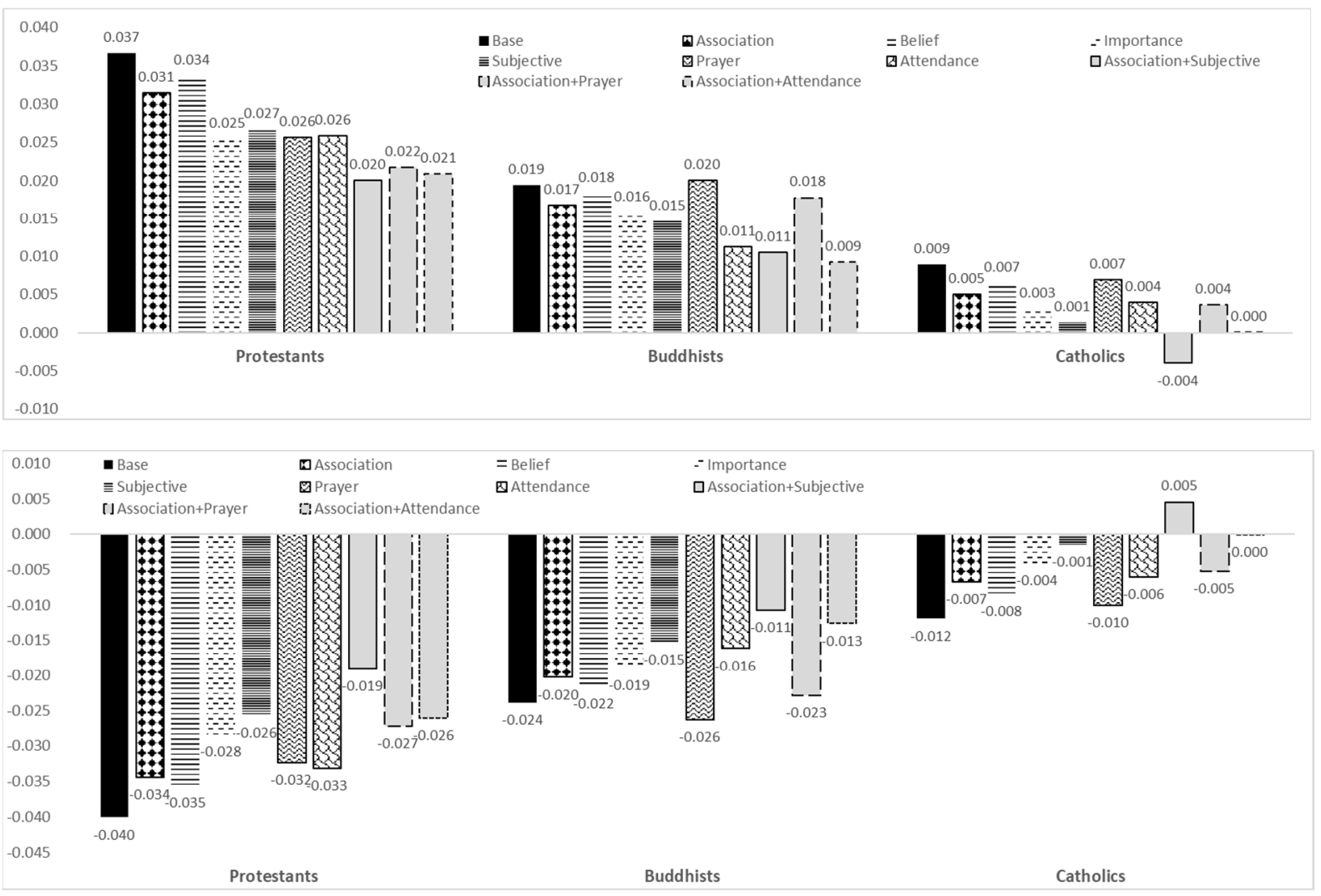

Figure 2. Differences in predicted probabilities of SOC being 10 (upper panel) and 5 (lower panel) among Protestants, Buddhists, and Catholics vis-à-vis non-affiliates. Note: Bars refer to the differences between affiliates (Protestants, Buddhists, or Catholics) and non-affiliates in the predicted probabilities for a hypothetical person (i.e., a mean-aged, college-or-moreeducated, and married female who is a part-time worker with the mean income) to have SOC at 10 (the highest level) and at 5 (a low level). Bars of "Base" are post-estimations from Model 1 of Table 2; "Association" from Model 2; "Belief" from Model 3; "Importance" from Model 4; "Subjective" from Model 5; "Prayer" from Model 6; "Attendance" from Model 7; "Association + Subjective" from Model 10; "Association + Prayer" from Model 11; "Association + Attendance" from Model 12.

To elaborate, the solid black bar in the far left group of the upper panel indicates that the probability of Protestants having SOC at 10 is higher than that for non-affiliates by 0.037; the solid black bar in the middle group of the upper panel shows that the probability of Buddhists having 10 in SOC is 0.019 greater than that for non-affiliates; the black bar in the far right group shows that the corresponding probability for Catholics is 0.009 higher than that for non-affiliates. The black bars in the lower panel, which refer to the probability differences when SOC is 5 , show exactly the opposite pattern. Taken together, these results support Hypothesis 1. 
Model 2 in Table 2 shows that the regression coefficients for religious affiliates become smaller than those in Model 1, supporting Hypothesis 2a. Civic associational memberships serve as a mediator in the positive relationship between religious affiliates and SOC; associational memberships have a positive relationship with SOC (coefficient $=0.06$ ), and affiliates have more associational memberships than non-affiliates (Panel 2 in Figure 1). The patterned bars (labeled "Association") following the solid black bars in Figure 2 visualize this mediation effect; the figure shows that the original probability differences between affiliates and non-affiliates obtained without considering the mediator (solid black bars labeled "Base") become smaller in the patterned bars of both panels when the mediator is considered.

Models 3 to 5 in Table 2 show that the regression coefficients for religious affiliates have all decreased from those in Model 1, supporting Hypothesis $2 b$ on the mediating effect of individual-affective action on the association between religious affiliates and SOC. Panels 3 to 5 in Figure 1 verify that affiliates are more likely to believe in God, acknowledge the importance of God in life, and consider themselves to be religious. In addition, these measures of individual-affective action have positive associations with SOC. As shown in Figure 2, the probability differences between affiliates and non-affiliates have decreased to the dashed bars labeled "Belief", "Importance", and "Subjective" that take into account the mediating effects of these three measures of individual-affective action.

Models 6 and 7 in Table 2 show that the regression coefficients for religious affiliates are reduced from those in Model 1, thus respectively supporting Hypotheses $2 c$ and $2 d$ on the mediating effects of prayer and religious service attendance on the relationship between religious affiliates and SOC. Affiliates are more likely to pray (Panel 6 of Figure 1) and attend religious services (Panel 7 of Figure 1); the bars labeled "Prayer" and "Attendance" visualize the respective mediating effects.

While all the hypotheses are supported by the results thus far, Models 8 to 12 in Table 2 reveal additional evidence: when I simultaneously consider both the secular and sacred aspects of religious action, the mediating effects of religious action become stronger. Specifically, the changes in the coefficients of affiliates are greater (Table 2) and the decreases in the probability differences between affiliates and non-affiliates (grey bars labeled "Association + Subjective", "Association + Prayer", and "Association + Attendance") are larger. These findings more directly support the multivocality of religious action, as they confirm that the meanings of religious action can be appreciated more comprehensively when its secular and sacred aspects are accounted for simultaneously.

I find these patterns of mediation to remain true in both a supplementary analysis of other East Asian countries (Japan and China) (online Supplementary Tables S1 and S2) and a multilevel analysis of 49 countries in the world (online Supplementary Table S3). The Chinese case is particularly worth mentioning. Religious affiliates in China feel less free and less in control of their life than non-affiliates, presumably because religious denominations are not socially sanctioned in the national political context (Hu et al. 2017). However, this discount in SOC among affiliates is smaller than the otherwise large discount when I take out the mediating effects of religious action. In other words, Chinese religious affiliates who practice little religious action feel the least SOC, whereas those affiliates who are active in religious action feel greater SOC. This result, which can also be confirmed in the multilevel cross-national analysis, supports the salutary mediating effects of religious action.

\section{Conclusions}

One of the critical insights from the sociology of action is that individual agency lies not only in the control of but also in submission to sociality of various kinds, such as interactional relations and supra-individual entities. The multidisciplinary literature about SOC is one of the promising endeavors to investigate such individual agency. The sociology of religion holds a special place in the literature, as it has addressed SOC in relation to a special kind of sociality, or deity. However, the results have unfortunately remained relatively inconclusive about how submission to deity affects SOC. 
By engaging the extant literature of religious practices from the perspective of action theory (Glaeser 2016; Joas and Beckert 2006), first, I make an original conceptual articulation that highlights and, subsequently, unpacks the multivocality of religiosity into categorical religiosity and substantive religiosity (or, religious action); religious action is further conceptualized to consist of individual-affective, individual-practical, and collectivepractical actions. Secondly, against this conceptual framework, I propose a mediation model in which categorical religiosity is related to SOC via the mediating effects of religious action. In specifying the model with empirical data, I demonstrate that categorical religiosity is varyingly related to SOC, that there is a positive relationship between categorical religiosity and religious action, and that religious action mediates the association between categorical religiosity and SOC (Models 2 to 7). Based on the results, I argue for the consistently beneficial effects of religious action on SOC as a mediator on the association between categorical religiosity and SOC. Thirdly, I find that these beneficial effects stem not only from sacred actions but from secular actions as well, and that these effects become more significant when sacred and secular practices are considered simultaneously (Models 8 to 12).

This secular-sacred intersection in religious action provides unique leverage with which to address the nature of individual agency. Given the empirical measures used, I particularly highlight that participation in sociality (i.e., via memberships to civic associations as well as religious organizations) exists together with submission to deity (i.e., via affects and practices toward deity) within religious action. Given this coexistence of participation and submission, it would be hardly persuasive to regard participation in sociality (i.e., in social relations) not as submission to sociality while regarding submission to deity not as participation in deity (i.e., in the relationship with deity). It would also be unpersuasive if participation were to be taken to only carry the active voices of actors with no passive voices of submission while submission was to be taken to only carry the passive voices with no active voices of participation. In this regard, a recent criticism is worth noting that agency in many sociological imaginations regrettably lies only in active intentionality (but not passive intentionality) and only in control (but not letting go) of the self and relations (Joas and Beckert 2006). Resonating with the criticism, my empirical findings suggest an alternative view: participation carries the passivity as well as proactivity of individuals; submission involves the proactivity as well as passivity of actors. Therefore, in terms of individual agency, submission and participation are the two sides of a single coin; individual agency lies in submission to as well as participation in sociality of a secular or sacred kind.

By stressing the coexistence and interplay of submission and participation, I ultimately argue for a third meaning of the multivocality of religious action. I have begun my inquiry with the conceptual clarification that religiosity is composed multivocally of categorical religiosity and religious action, on the one hand, and that religious action involves multivocally both secular and sacred practices, on the other. I now stress that religious action is multivocal to the extent that it is participatory as well as submissive, active as well as passive, and free as well as obligated.

Supplementary Materials: The following are available online at https:/ / www.mdpi.com/2077-1 444/12/2/117/s1, Table S1: Logged odds ratios from ordered logistic regression models of SOC upon affiliational status, mediators, and other covariates (Japan), Table S2: Logged odds ratios from ordered logistic regression models of SOC upon affiliational status, mediators, and other covariates (China), Table S3: Logged odds ratios from multi-level ordered logistic regression models of SOC upon affiliational status, mediators, and other covariates (WVS wave 6 in 49 countries), Table S4: Coefficients from ordinary least squared (OLS) regression models of SOC upon affiliational status, mediators, and other covariates (Korea), Table S5: Coefficients from ordinary least squared (OLS) regression models of SOC upon affiliational status, mediators, and other covariates (Japan), Table S6: Coefficients from ordinary least squared (OLS) regression models of SOC upon affiliational status, mediators, and other covariates (China), Table S7: Coefficients from multi-level ordinary least squared (OLS) regression models of SOC upon affiliational status, mediators, and other covariates (WVS wave 6 in 49 countries). 
Funding: This work was supported by the Ministry of Education of the Republic of Korea and the National Research Foundation of Korea (NRF-2020S1A5A2A01043365).

Data Availability Statement: Data is available from WVS database at http:/ / www.worldvaluessurvey. org/wvs.jsp.

Conflicts of Interest: The author declares no conflict of interest.

\section{References}

Alexander, Jeffrey C. 1987. Twenty Lectures: Sociological Theory Since World War II. New York: Columbia University Press.

Allport, Gordon. W. 1950. The Individual and His Religion: A Psychological Interpretation. New York: The Macmillan Company.

Ammerman, Nancy T. 2020. Rethinking Religion: Toward a Practice Approach. American Journal of Sociology 126: 6-51. [CrossRef]

Anheier, Helmut, and Jeremy Kendall. 2002. Interpersonal trust and voluntary associations: Examining three approaches. The British Journal of Sociology 53: 343-62. [CrossRef] [PubMed]

Baker, Joseph O'Brian, and Buster Smith. 2009. None Too Simple: Examining Issues of Religious Nonbelief and Nonbelonging in the United States. Journal for the Scientific Study of Religion 48: 719-33. [CrossRef]

Berger, Peter L. 2011. The Sacred Canopy: Elements of a Sociological Theory of Religion. New York: Open Road Media. First published 1967.

Black, Helen K. 1999. Poverty and Prayer: Spiritual Narratives of Elderly African-American Women. Review of Religious Research 40: 359-74. [CrossRef]

Bobkowski, Piotr S., and Sriram Kalyanaraman. 2010. Effects of online Christian self-disclosure on impression formation. Journal for the Scientific Study of Religion 49: 456-76. [CrossRef]

Chan, Cheris Shun-Ching. 2000. The Sacred-Secular Dialectics of the Reenchanted Religious Order-The Lingsu Exo-Esoterics in Hong Kong. Journal of Contemporary Religion 15: 45-63. [CrossRef]

Clements, Ben. 2014. Religion and the Sources of Public Opposition to Abortion in Britain: The Role of 'Belonging', 'Behaving' and 'Believing'. Sociology-The Journal of the British Sociological Association 48: 369-86. [CrossRef]

Cole, Brenda S., and Kenneth I. Pargament. 1999. Spiritual surrender: A paradoxical path to control. In Integrating Spirituality into Treatment: Resources for Practitioners. Washington, DC: American Psychological Association, pp. 179-98.

Davis, James A. 1985. The Logic of Causal Order. London: Sage.

Demerath, Nicholas Jay. 2000. The varieties of sacred experience: Finding the sacred in a secular grove. Journal for the Scientific Study of Religion 39: 1-11. [CrossRef]

Demerath, Nicholas Jay, Peter Dobkin Hall, Rhys H. Williams, and Terry Schmitt. 1998. Sacred Companies: Organizational Aspects of Religion and Religious Aspects of Organizations. Oxford: Oxford University Press.

DiMaggio, Paul. 1998. The Relevance of Organization Theory to the Study of Religion. In Sacred Companies: Organizational Aspects of Religion and Religious Aspects of Organizations. Edited by Nicholas J. Demerath, Peter D. Hall and Terry Schmitt. Oxford: Oxford University Press, pp. 7-23.

Downey, Geraldine, and Phyllis Moen. 1987. Personal Efficacy, Income, and Family Transitions: A Longitudinal Study of Women Heading Households. Journal of Health and Social Behavior 28: 320-33. [CrossRef]

Durkheim, Émile. 1995. The Elementary Forms of Religious Life. New York: The Free Press. First published 1912.

Eliade, Mircea. 1959. The Sacred and the Profane: The Nature of Religion. Boston: Houghton Mifflin Harcourt.

Ellison, Christopher G. 1993. Religious Involvement and Self-Perception among Black Americans. Social Forces 71: 1027-55. [CrossRef]

Ellison, Christopher G., and Amy M. Burdette. 2012. Religion and the Sense of Control among U.S. Adults. Sociology of Religion 73: 1-22. [CrossRef]

Ellison, Christopher G., and Linda K. George. 1994. Religious Involvement, Social Ties, and Social Support in a Southeastern Community. Journal for the Scientific Study of Religion 33: 46-61. [CrossRef]

Emirbayer, Mustafa, and Ann Mische. 1998. What Is Agency? American Journal of Sociology 103: 962-1023. [CrossRef]

Ferraro, Kenneth F., and Jessica A. Kelley-Moore. 2001. Religious Seeking among Affiliates and Non-Affiliates: Do Mental and Physical Health Problems Spur Religious Coping? Review of Religious Research 42: 229-51. [CrossRef]

Foucault, Michel. 1982. The Subject and Power. Critical Inquiry 8: 777-95. [CrossRef]

Foucault, Michel. 1991. Governmentality. In The Foucault Effect: Studies in Governmentality. Edited by Graham Burchell, Colin Gordon and Peter Miller. Chicago: The University of Chicago Press, pp. 87-104. First published 1978.

Friedland, Roger. 2013. The gods of institutional life: Weber's value spheres and the practice of polytheism. Critical Research on Religion 1: 15-24. [CrossRef]

Glaeser, Andreas. 2016. Action in Society: Reflexively Conceptualizing Activities. In Handbook of Contemporary Sociological Theory. Edited by Seth Abrutyn. Switzerland: Springer, pp. 63-84.

Glock, Charles Y. 1962. On the Study of Religious Commitment. Religious Education 57: 98-110.

Gritzmacher, Steven A., Brian Bolton, and Richard H. Dana. 1988. Psychological characteristics of Pentecostals: A literature review and psychodynamic synthesis. Journal of Psychology and Theology 16: 233-45. [CrossRef]

Heuser, Andreas. 2016. Charting African Prosperity Gospel economies. HTS Theological Studies 72: 1-9. [CrossRef]

Holdo, Markus. 2018. The Virtuous, the Critical and the Trustworthy: Citizen Ideals and Forms of Democratic Participation. Scandinavian Political Studies 41: 1-21. [CrossRef] 
$\mathrm{Hu}$, Anning, Xiaozhao Yousef Yang, and Weixiang Luo. 2017. Christian Identification and Self-Reported Depression: Evidence from China. Journal for the Scientific Study of Religion 56: 765-80. [CrossRef]

Joas, Hans. 1996. The Creativity of Action. Chicago: The University of Chicago Press.

Joas, Hans, and Jens Beckert. 2006. Action Theory. In Handbook of Sociological Theory. Edited by Jonathan H. Turner. Switzerland: Springer, pp. 269-85.

Joas, Hans, and Wolfgang Knöbl. 2009. Social Theory: Twenty Introductory Lectures. Cambridge: Cambridge University Press.

Jung, Jong Hyun. 2019. Religion and the Sense of Control in Cross-National Perspective: The Importance of Religious Context. Social Currents 6: 67-87. [CrossRef]

Kalberg, Stephen. 1980. Max Weber's Types of Rationality: Cornerstones for the Analysis of Rationalization Processes in History. American Journal of Sociology 85: 1145-79. [CrossRef]

Kim, Jibum, Yongmo Lee, Jaesok Son, and Tom W. Smith. 2009. Trends of Religious Identification in Korea: Changes and Continuities. Journal for the Scientific Study of Religion 48: 789-93. [CrossRef]

Kinnvall, Catarina. 2004. Globalization and Religious Nationalism: Self, Identity, and the Search for Ontological Security. Political Psychology 25: 741-67. [CrossRef]

Krause, Neal, and R. David Hayward. 2013. Emotional expressiveness during worship services and life satisfaction: Assessing the influence of race and religious affiliation. Mental Health, Religion $\mathcal{E}$ Culture 16: 813-31.

Lazarus, Suleman. 2019. Where Is the Money? The Intersectionality of the Spirit World and the Acquisition of Wealth. Religions 10: 146. [CrossRef]

Lee, Chengpang, and Myungsahm Suh. 2017. State Building and Religion: Explaining the Diverged Path of Religious Change in Taiwan and South Korea, 1950-1980. American Journal of Sociology 123: 465-509. [CrossRef]

Long, J. Scott, and Jeremy Freese. 2014. Regression Models for Categorical Dependent Variables Using Stata, 3rd ed. College Station: Stata Press.

Lynch, Gordon. 2012. The Sacred in the Modern World: A cultural Sociological Approach. Oxford: Oxford University Press.

Masters, Kevin S., and Kenneth A. Wallston. 2005. Canonical Correlation Reveals Important Relations between Health Locus of Control, Coping, Affect and Values. Journal of Health Psychology 10: 719-31. [CrossRef]

Mauss, Marcel. 1990. The Gift: The Form and Reason for Exchange in Archaic Societies. New York: W. W. Norton. First published 1950.

McIntosh, W. Alex, and Jon P. Alston. 1982. Lenski Revisited: The Linkage Role of Religion in Primary and Secondary Groups. American Journal of Sociology 87: 852-82.

Norris, Pippa, and Ronald Inglehart. 2011. Sacred and Secular: Religion and Politics Worldwide, 2nd ed.Cambridge: Cambridge University Press.

Olson, Laura R., and Adam L. Warber. 2008. Belonging, behaving, and believing: Assessing the role of religion on presidential approval. Political Research Quarterly 61: 192-204. [CrossRef]

Pargament, Kenneth I. 2002. The Bitter and the Sweet: An Evaluation of the Costs and Benefits of Religiousness. Psychological Inquiry 13: 168-81. [CrossRef]

Pargament, Kenneth I., Joseph Kennell, William Hathaway, Nancy Grevengoed, Jon Newman, and Wendy Jones. 1988. Religion and the Problem-Solving Process: Three Styles of Coping. Journal for the Scientific Study of Religion 27: 90-104. [CrossRef]

Pascoe, Anita E., Terrence D. Hill, Krysia N. Mossakowski, and Robert J. Johnson. 2016. Religious Involvement and Perceptions of Control: Evidence from the Miami-Dade Health Survey. Journal of Religion and Health 55: 862-73. [CrossRef] [PubMed]

Pearlin, Leonard I., Elizabeth G. Menaghan, Morton A. Lieberman, and Joseph T. Mullan. 1981. The Stress Process. Journal of Health and Social Behavior 22: 337-56. [CrossRef] [PubMed]

Perkins, H. Wesley. 1985. A Research Note on Religiosity as Opiate or Prophetic Stimulant among Students in England and the United States. Review of Religious Research 26: 269-80. [CrossRef]

Pollner, Melvin. 1989. Divine Relations, Social Relations, and Well-Being. Journal of Health and Social Behavior 30: 92-104. [CrossRef]

Reed, Isaac A. 2013. Power: Relational, Discursive, and Performative Dimensions. Sociological Theory 31: 193-218. [CrossRef]

Reeves, Roy R., Claire E. Adams, Patricia M. Dubbert, DeMarc A. Hickson, and Sharon B. Wyatt. 2012. Are Religiosity and Spirituality Associated with Obesity Among African Americans in the Southeastern United States (the Jackson Heart Study)? Journal of Religion and Health 51: 32-48. [CrossRef]

Ross, Catherine E., and John Mirowsky. 2013. The Sense of Personal Control: Social Structural Causes and Emotional Consequences. In Handbook of the Sociology of Mental Health. Edited by Carol S. Aneshensel, Jo C. Phelan and Alex Bierman. New York: Springer, pp. 379-402.

Saroglou, Vassilis. 2011. Believing, Bonding, Behaving, and Belonging: The Big Four Religious Dimensions and Cultural Variation. Journal of Cross-Cultural Psychology 42: 1320-40. [CrossRef]

Schieman, Scott. 2008. The Religious Role and the Sense of Personal Control. Sociology of Religion 69: 273-96. [CrossRef]

Schieman, Scott, Tetyana Pudrovska, and Melissa A. Milkie. 2005. The Sense of Divine Control and the Self-Concept: A Study of Race Differences in Late Life. Research on Aging 27: 165-96. [CrossRef]

Schnabel, Landon, and Sean Bock. 2017. The persistent and exceptional intensity of American religion: A response to recent research. Sociological Science 4: 686-700. [CrossRef]

Shrout, Patrick E., and Niall Bolger. 2002. Mediation in Experimental and Nonexperimental Studies: New Procedures and Recommendations. Psychological Methods 7: 422-45. [CrossRef] [PubMed] 
Smith, Christian, and Patricia Snell. 2009. Souls in Transition: The Religious and Spiritual Lives of Emerging Adults. Oxford: Oxford University Press.

Speed, David, and Ken Fowler. 2017. Empowerment or dependency? The religion/religiosity-mastery relationship. Canadian Psychology/Psychologie Canadienne 58: 333-44. [CrossRef]

Storm, Ingrid. 2011. Ethnic nominalism and civic religiosity: Christianity and national identity in Britain. The Sociological Review 59: 828-46. [CrossRef]

Storm, Ingrid. 2018. When does religiosity matter for attitudes to immigration? The impact of economic insecurity and religious norms in Europe. European Societies 20: 595-620. [CrossRef]

Taylor, Charles. 2007. A Secular Age. Cambridge: Harvard university press.

Thiessen, Joel, and Sarah Wilkins-Laflamme. 2017. Becoming a Religious None: Irreligious Socialization and Disaffiliation. Journal for the Scientific Study of Religion 56: 64-82. [CrossRef]

Vernon, Glenn M. 1968. The Religious “Nones”: A Neglected Category. Journal for the Scientific Study of Religion 7: 219-29. [CrossRef]

Voas, David. 2007. Surveys of Behaviour, Beliefs and Affiliation: Micro-Quantitative. In The SAGE Handbook of the Sociology of Religion. Edited by James A. Beckford and Nicholas J. Demerath III. Singapore: Sage, pp. 144-166.

Voas, David, and Mark Chaves. 2018. Even intense religiosity is declining in the United States: Comment. Sociological Science 5: 694-710. [CrossRef]

Wuthnow, Robert. 2010. After the Baby Boomers: How Twenty-and Thirty-Somethings Are Shaping the Future of American Religion. Princeton: Princeton University Press. 